\title{
PENERAPAN F-TOPSIS DALAM ANALISIS FUNDAMENTAL BERDASARKAN RASIO KEUANGAN UNTUK MENUNJANG KEPUTUSAN BERINVESTASI SAHAM
}

\author{
Angger Binuko Paksi \\ Teknik Informatika STMIK AMIKOM Yogyakarta \\ $J$ Ring road Utara, Condongcatur, Sleman, Yogyakarta 55281 \\ Email : angger.binuko@gmail.com
}

\begin{abstract}
Abstrak
Investasi saham merupakan satu dari sekian banyak pilihan berinvestasi yang semakin diminati oleh berbagai kalangan. Dalam berinvestasi saham, pergerakan nilai saham suatu perusahaan dipengaruhi oleh beberapa faktor. Dengan demikian dibutuhkan suatu analisis dan tindakan yang tepat dalam berinvestasi di pasar saham agar seorang investor dapat berinvestasi sesuai kebutuhannya.Salah satu caranya dengan analisis fundamental. Analisis fundamental merupakan metode analisis yang menitikberatkan pada data-data kunci yang ada dalam laporan keuangan suatu perusahaan untuk menilai kinerja keuangan perusahaan. Rasio keuangan merupakan alat untuk mengevaluasi kinerja perusahaan berdasarkan datadata yang ada pada laporan keuangan. Rasio keuangan secara umum meliputi rasio likuiditas, rasio solvabilitas, rasio aktivitas, rasio profitabilitas dan rasio pasar. Metode FTOPSIS (Fuzzy Technique for Order Preference by Similarity to Ideal Solution) menggunakan prinsip bahwa alternatif yang terpilih harus mempunyai jarak terdekat dari solusi ideal positif dan terjauh dari solusi ideal negatif untuk menentukan kedekatan relatif dari suatu alternatif dengan solusi optimal, penggunaan bilangan fuzzy dalam metode ini memberikan efektifitas dalam menentukan nilai matriks keputusan. Dari pengolahan data laporan keuangan akan didapatkan hasil analisis rasio keuangan yang nantinya akan diproses dengan metode TOPSIS untuk menghasilkan rekomendasi berinvestasi saham dari beberapa alternatif perusahaan yang terdaftar pada Bursa Efek Indonesia.
\end{abstract}

Kata kunci: Analisis Fundamental Saham, Rasio Keuangan, Fuzzy, TOPSIS, Sistem Pendukung Keputusan.

\section{Pendahuluan}

Investasi merupakan suatu langkah seseorang dalam pemenuhan kebutuhan di masa yang akan datang. Investasi saham merupakan satu dari sekian banyak pilihan investasi yang semakin diminati oleh berbagai kalangan. Dalam berinvestasi saham, pergerakan nilai saham suatu perusahaan dipengaruhi oleh beberapa faktor. Dengan demikian dibutuhkan suatu analisis dan tindakan yang tepat dalam berinvestasi di pasar saham agar seorang investor dapat berinvestasi sesuai kebutuhannya. Prediksi pergerakan suatu saham dapat dilakukan dengan dua cara, yaitu dengan menggunakan analisis fundamental dan analisis teknikal.

Analisis fundamental merupakan metode analisis yang menggunakan studi tentang keadaan ekonomi, industri, dan kondisi perusahaan untuk menentukan nilai wajar dari harga saham perusahaan. Analisis fundamental menitikberatkan pada data-data kunci yang ada dalam laporan keuangan perusahaan untuk mempertimbangkan apakah harga saham sudah atau belum diapresiasi secara cepat [1]. Sedangkan analisis teknikal merupakan sebuah metode yang paling dasar dalam investasi di pasar modal dengan mengamati grafik pergerakan harga dan volume saham.

Dari kondisi yang telah penulis jabarkan diatas mendorong penulis untuk membuat penelitian terkait sistem pendukung keputusan untuk memberikan rekomendisi berinsvestasi saham dengan analisis fundamental saham berdasarkan rasio keuangan. Untuk mewujudkannya penulis akan menggunakan data-data dari laporan keuangan perusahaan (emiten) yang terdaftar pada index Bursa Efek Indonesia. Data Sekunder berupa laporan keuangan didapat pada situs resmi Bursa Efek Indonesia dan telah dinyatakan lolos audit, sehingga data-data yang akan digunakan dalam penelitian ini terjamin validitasnya.

Metode pendukung keputusan yang akan digunakan pada penelitian ini adalah metode FTOPSIS karena metode ini menggunakan prinsip bahwa alternatif yang terpilih harus mempunyai jarak terdekat dari solusi ideal positif dan terjauh dari solusi ideal negatif dari sudut pandang geometris dengan menggunakan jarak Euclidean untuk menentukan kedekatan relatif dari suatu alternatif dengan solusi optimal [2], serta penggunaan bilangan fuzzy dalam metode ini memberikan efektifitas dalam menentukan nilai matriks keputusan. Dengan pengaplikasian metode FTOPSIS dalam membuat rekomendasi saham berdasarkan analisis rasio keuangan, diharapkan dapat membantu para investor untuk menentukan pilihan berinvestasi saham tanpa harus membuang banyak waktu untuk melakukan perhitungan manual. 
Penelitian ini akan memfokuskan pada rumusan masalah sebagai berikut:

1. Bagaimana menganalisis laporan keuangan perusahaan yang terdaftar dalam Bursa Efek Indonesia berdasarkan rasio keuangan?

2. Bagaimana menerapkan metode F-TOPSIS untuk menghasilkan sebuah rekomendasi alternatif dalam berinvestasi di pasar saham?

Beberapa penelitian yang dapat dijadikan tinjauan pustaka diantaranya adalah penelitian dari Sri Lestari (2011), dimana dalam penelitiannya membahas tentang implementasi metode Fuzzy Technique for Order Preference by Similarity to Ideal Solution untuk proses penyeleksian penerimaan karyawan [3]. Rajim Laymond S (2013) dalam penelitian membahas pembangunan sistem pendukung keputusan pemilihan saham berbasis web dengan pemodelan Analytical Hierarchy Process (AHP) serta analisis rasio keuangan berdasarkan ROE dan ROA [4]. Dedy Hartama (2014) dalam penelitiannya menjelaskan bahwa metode Fuzzy-TOPSIS dapat digunakan dalam kasus seleksi dosen berprestasi [5]. Yan Satria Setyawan, Wayan Firdaus Mahmudy, Indriati (2015) membahas tentang penerapan Metode Fuzzy Analitycal Hierarchy Process (F-AHP) sebagai pendukung keputusan investasi pada perusahaan berdasarkan rasio keuangan [6]. Hence B. Lumentut (2015) dalam penelitiannya membahas tentang penggunaan metode AF-TOPSIS dalam menentukan jenis budidaya ikan air tawar dengan menggunakan parameter kondisi lingkungan air dan faktor finansial [7].

\section{Analisis Rasio Keuangan}

Analisis rasio keuangan merupakan alat untuk mengevaluasi kinerja perusahaan berdasarkan data-data yang ada pada laporan keuangan. Tabel 1 menunjukkan jenis-jenis rasio yang akan dijadikan fokus pembahasan dalam penelitian ini [8][9].

Tabel 1. Kelompok rasio keuangan

\begin{tabular}{|l|l|c|}
\hline Kelompok Rasio & Jenis rasio & \multicolumn{1}{c|}{ Rumus } \\
\hline Rasio Likuiditas & Current Ratio & $\frac{\text { Aset Lancar }}{\text { Kewajiban Jangka Pendek }}$ \\
\cline { 2 - 3 } & Quick Ratio & $\frac{\text { Aset Lancar - Persediaan) }}{\text { Kewajiban Jangka Pendek }}$ \\
\cline { 2 - 3 } & Cash Ratio & $\frac{\text { Kas dan Setara Kas }}{\text { Rewajiban Jangka Pendek }}$ \\
\hline \multirow{5}{*}{ Rasio Solvabilitas } & Debt to Asset Ratio & $\frac{\text { Total Kewajiban }}{\text { Total Aset }}$ \\
\cline { 2 - 3 } & Debt to Equity Ratio & $\frac{\text { Total Kewajiban }}{\text { Total Ekuitas }}$ \\
\cline { 2 - 3 } & $\begin{array}{l}\text { Long Term Debt to Equity } \\
\text { Ratio }\end{array}$ & $\frac{\text { Kewajiban Jangka Panjang }}{\text { Rotal Ekuitas }}$ \\
\cline { 2 - 3 } & Equity Multiplier & $\frac{\text { Total Aset }}{\text { Total Ekuitas }}$ \\
\hline \multirow{5}{*}{ Rasio Aktivitas } & Accounts Receivable Turnover & $\frac{\text { Penjualan Neto }}{\text { Rata-rata Piutang }}$ \\
\cline { 2 - 3 } & Inventory Turnover & $\frac{\text { Beban Pokok Penjualan }}{\text { Rata-rata Persediaan }}$ \\
\cline { 2 - 3 } & &
\end{tabular}

\begin{tabular}{|c|c|c|}
\hline & Working Capital Turnover & $\frac{\text { Penjualan Neto }}{\text { Rata-rata Aset Lancar }}$ \\
\hline & Fixed Assets Turnover & $\frac{\text { Penjualan Neto }}{\text { Rata-rata Aset Tetap }}$ \\
\hline & Total Assets Turnover & $\frac{\text { Penjualan Neto }}{\text { Rata-rata Total Aset }}$ \\
\hline \multirow[t]{5}{*}{$\begin{array}{l}\text { Rasio } \\
\text { Profitabilitas }\end{array}$} & Return on Assets & $\frac{\text { Laba Bersih }}{\text { Total Aset }}$ \\
\hline & Return on Equity & $\frac{\text { Laba Bersih }}{\text { Total Ekuitas }}$ \\
\hline & Gross Profit Margin & $\frac{\text { Laba Kotor }}{\text { Penjualan Neto }}$ \\
\hline & Operating Profit Margin & $\frac{\text { Laba Usaha }}{\text { Penjualan Neto }}$ \\
\hline & Net Profit Margin & $\frac{\text { Laba Bersih }}{\text { Penjualan Neto }}$ \\
\hline \multirow[t]{2}{*}{ Rasio Pasar } & Price Earnings Ratio & $\frac{\text { Harga Saham Per Lembar }}{\text { Laba Per Saham }}$ \\
\hline & Price to Book Value Ratio & $\frac{\text { Harga Saham Per Lembar }}{\left(\frac{\text { Total Ekuitas }}{\text { Jumlah Saham Beredar }}\right)}$ \\
\hline
\end{tabular}

\section{Fungsi Keanggotan Fuzzy}

Representasi linear naik, dimulai pada nilai domain yang memiliki derajat keanggotaan nol (0) bergerak ke kanan menuju ke nilai domain yang memiliki derajat keanggotaan lebih tinggi (Gambar 1).

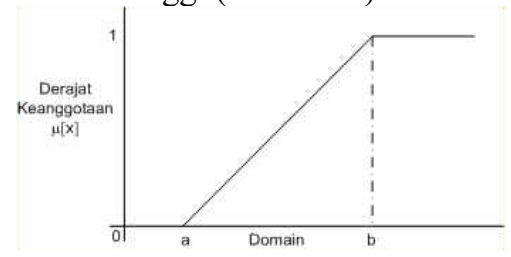

Gambar 1. Representasi linear naik

Fungsi keanggotaan:

$$
\mu[\mathrm{x}]= \begin{cases}0 ; & x \leq a \\ (x-a) /(b-a) ; & a \leq x \leq b \\ 1 ; & x \geq b\end{cases}
$$

Representasi linear turun, dimulai dari nilai domain dengan derajat keanggotaan tertinggi pada sisi kiri, kemudian bergerak menurun ke nilai domain yang memiliki derajat keanggotaan lebih rendah (Gambar 2).

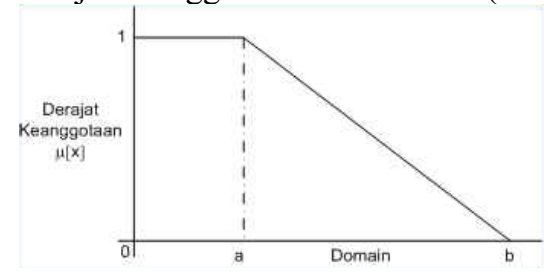

Gambar 2. Representasi linear turun

Fungsi keanggotaan:

$\mu[\mathrm{x}]= \begin{cases}1 ; & x \leq a \\ (b-x) /(b-a) ; & a \leq x \leq b \\ 0 ; & x \geq b\end{cases}$

\section{Metode TOPSIS}

Ada beberapa langkah kerja dalam TOPSIS yaitu [2]:

1. Membuat matriks keputusan ternormalisasi, TOPSIS membutuhkan rating kinerja setiap alternatif $\mathrm{A}_{\mathrm{i}}$ pada 
setiap kriteria $\mathrm{C}_{\mathrm{i}}$ yang ternormalisasi, berdasarkan persamaan:

$$
r \mathrm{ij}=\frac{x_{i j}}{\sqrt{\sum_{i=1}^{m} x_{i j}^{2}}} ; \mathrm{i}=1,2, \ldots, \mathrm{m} ; \text { dan } \mathrm{j}=1,2, \ldots, \mathrm{n}
$$

2. Membuat matriks keputusan ternormalisasi terbobot dengan mengalikan bobot $\mathrm{w}_{\mathrm{i}}$ dengan rating kerja $\mathrm{r}_{\mathrm{ij}}$ yang akan menghasilkan matriks $\mathrm{y}_{\mathrm{ij}}$, berdasarkan persamaan:

$Y \mathrm{ij}=$ wi $r \mathrm{ij} ; \mathrm{i}=1,2, \ldots, \mathrm{m} ; \operatorname{dan} \mathrm{j}=1,2, \ldots, \mathrm{n}$

3. Menentukan matriks solusi ideal positif $\left(A^{+}\right)$dan matriks solusi ideal negatif $\left(A^{-}\right)$berdasarkan rating bobot ternormalisasi $\mathrm{y}_{\mathrm{ij}}$

$A^{+}=\left(y_{1}^{+}, y_{2}^{+}, \ldots, y_{n}^{+}\right)$

$A^{-}=\left(y_{1}^{-}, y_{2}^{-}, \ldots, y_{n}^{-}\right)$

dengan,

$y_{J}^{+}= \begin{cases}\max _{i} y_{i j} & ; \mathrm{jika} \mathrm{j}=\text { keuntungan (benefit) } \\ \min _{i} y_{i j} & ; \mathrm{jika} \mathrm{j}=\text { biaya }(\text { cost })\end{cases}$
$y_{J}^{-}= \begin{cases}\max _{i} y_{i j} & ; \mathrm{jika} \mathrm{j}=\operatorname{keuntungan}(\text { benefit }) \\ \min _{i} y_{i j} & ; \mathrm{jika} \mathrm{j}=\text { biaya }(\text { cost })\end{cases}$
$\mathrm{j}=1,2, \ldots, \mathrm{n}$

4. Menentukan jarak antara nilai setiap alternatif dengan matriks solusi ideal positif dan matriks solusi ideal negatif.

Jarak antara alternatif $\mathrm{A}_{\mathrm{i}}$ dengan solusi ideal positif dirumuskan dalam persamaan:

$D_{i}^{+}=\sqrt{\sum_{j=1}^{n}\left(y_{i j}-y_{i j}^{+}\right)^{2}}$

Jarak antara alternatif $A_{i}$ dengan solusi ideal negatif dirumuskan dalam persamaan:

$D_{i}^{-}=\sqrt{\sum_{j=1}^{n}\left(y_{i j}-y_{i j}^{-}\right)^{2}}$

5. Menentukan nilai preferensi untuk setiap alternatif

$\left(V_{i}\right)$ dengan persamaan:

$V_{i}=\frac{D^{-}}{D_{i}^{-}+D_{i}^{+}} ; 0<\mathrm{V}_{\mathrm{i}}<1$ dan $\mathrm{i}=1,2,3, \ldots, \mathrm{n}$

\section{Pembahasan}

Data yang digunakan dalam penelitian merupakan data sekunder berupa laporan keuangan tahunan yang didapat dari situs resmi Bursa Efek Indonesia (www.idx.co.id). Laporan keuangan akan diolah menggunakan analisis rasio keuangan untuk mendapatkan nilai rasio-rasio yang akan diproses dengan FTOPSIS untuk menghasilkan suatu rekomendasi dari alternatif yang ada. Ada 3 alternatif saham yang akan dijadikan contoh pembahasan dalam penelitian ini, yaitu Indofood Sukses Makmur Tbk (INDF), Kalbe Farma Tbk (KLBF), dan Unilever Indonesia Tbk (UNVR).

\subsection{Analisis Laporan Keuangan}

Dari laporan keuangan masing-masing alternatif perusahaan pada tahun 2014 didapatkan data-data seperti pada tabel 2:
Tabel 2. Data laporan keuangan

\begin{tabular}{|l|r|r|r|}
\hline ITEM /PERUSAHAAN & \multicolumn{1}{|c|}{ INDF } & \multicolumn{1}{c|}{ KLBF } & \multicolumn{1}{c|}{ UNVR } \\
\hline Aset Lancar & $40,995,736,000,000$ & $8,120,805,370,192$ & $6,337,170,000,000$ \\
\hline Kas dan Setara Kas & $14,157,619,000,000$ & $1,894,609,528,205$ & $859,127,000,000$ \\
\hline Piutang & $4,957,696,000,000$ & $2,464,901,529,716$ & $2,895,515,000,000$ \\
\hline Persediaan & $8,454,845,000,000$ & $3,090,544,151,155$ & $2,325,989,000,000$ \\
\hline Aset Tetap & $22,011,488,000,000$ & $3,404,457,131,056$ & $7,348,025,000,000$ \\
\hline Total Aset & $85,938,885,000,000$ & $12,425,032,367,729$ & $14,280,670,000,000$ \\
\hline Kewajiban Jangka Pendek & $22,681,686,000,000$ & $2,385,920,172,489$ & $8,864,832,000,000$ \\
\hline Kewajiban Jangka Panjang & $16,837,876,000,000$ & $221,636,516,794$ & $817,056,000,000$ \\
\hline Total Kewajiban & $44,710,509,000,000$ & $1,607,556,689,283$ & $9,681,888,000,000$ \\
\hline Total Ekuitas & $41,228,376,000,000$ & $9,817,475,678,446$ & $4,598,782,000,000$ \\
\hline Penjualan/Pendapatan Neto & $63,594,452,000,000$ & $17,368,532,547,558$ & $34,511,534,000,000$ \\
\hline Beban Pokok Penjualan & $46,544,646,000,000$ & $8,892,737,389,731$ & $17,412,413,000,000$ \\
\hline Laba Kotor & $17,049,806,000,000$ & $2,475,795,157,827$ & $17,099,121,000,000$ \\
\hline Laba Usaha/Operasional & $7,208,732,000,000$ & $2,761,064,040,213$ & $7,762,328,000,000$ \\
\hline Laba Bersih & $4,812,618,000,000$ & $2,121,090,581,630$ & $5,738,523,000,000$ \\
\hline Laba Per Saham (EPS) & 442 & 285 & 752 \\
\hline Harga Saham Per Lembar & 6,225 & 1,460 & 38,425 \\
\hline Jumlah Saham Beredar & $8,780,426,500$ & $46,875,122,110$ & $7,630,000,000$ \\
\hline
\end{tabular}

Dari data-data laporan keuangan yang telah diringkas, dilakukan analisis rasio keuangan dan didapatkan hasil seperti tabel 3:

Tabel 3. Tabel hasil analisis rasio keuangan

\begin{tabular}{|l|r|r|r|}
\hline RASIO LIKUIDITAS & \multicolumn{1}{|c|}{ INDF } & \multicolumn{1}{c|}{ KLBF } & \multicolumn{1}{c|}{ UNVR } \\
\hline Current Ratio & 1.807 & 3.404 & 0.715 \\
\hline Quick Ratio & 1.435 & 2.108 & 0.452 \\
\hline Cash Ratio & 0.624 & 0.794 & 0.097 \\
\hline RASIO SOLVABILITAS & \multicolumn{1}{|c|}{ INDF } & \multicolumn{1}{c|}{ KLBF } & \multicolumn{1}{c|}{ UNVR } \\
\hline Debt to Asset Ratio & 0.520 & 0.129 & 0.678 \\
\hline Debt to Equity Ratio & 1.084 & 0.164 & 2.105 \\
\hline Long Term Debt to Equty Ratio & 0.408 & 0.023 & 0.178 \\
\hline Equity Multiplier & 2.084 & 1.266 & 3.105 \\
\hline RASIO AKTIVITAS & INDF & KLBF & UNVR \\
\hline Accounts Receivable Turnover & 12.827 & 7.046 & 11.919 \\
\hline Inventory Turnover & 5.505 & 2.877 & 7.486 \\
\hline Working Capital Turnover & 1.551 & 2.139 & 5.446 \\
\hline Fixed Assets Turnover & 2.889 & 5.102 & 4.697 \\
\hline Total Assets Turnover & 0.740 & 1.398 & 2.417 \\
\hline RASIO PROFITABILITAS & INDF & KLBF & UNVR \\
\hline Return on Assets & $5.60 \%$ & $17.07 \%$ & $40.18 \%$ \\
\hline Return on Equity & $11.67 \%$ & $21.61 \%$ & $124.78 \%$ \\
\hline Gross Profit Margin & $26.81 \%$ & $14.25 \%$ & $49.55 \%$ \\
\hline Operating Profit Margin & $11.34 \%$ & $15.90 \%$ & $22.49 \%$ \\
\hline Net Profit Margin & $7.57 \%$ & $12.21 \%$ & $16.63 \%$ \\
\hline RASIO PASAR & INDF & KLBF & UNVR \\
\hline Price Earnings Ratio & 14.084 & 5.123 & 51.097 \\
\hline Price to Book Value Ratio & 1.326 & 6.971 & 63.752 \\
\hline
\end{tabular}

Dari proses analisis rasio keuangan didapatkan data-data kriteria diantaranya adalah: Current Ratio, Quick Ratio, Cash Ratio, Debt to Asset Ratio, Debt to Equity Ratio, Long Term Debt to Equty Ratio, Equity Multiplier, Accounts Receivable Turnover, Inventory Turnover, Working Capital Turnover, Fixed Assets Turnover, Total Assets Turnover, Return on Assets, Return on Equity, Gross Profit Margin, Operating Profit Margin, Net Profit Margin, Price Earnings Ratio, dan Price to Book Value Ratio.

\subsection{Metode FTOPSIS}

\section{Menentukan matriks keputusan}

Dalam rasio keuangan ada acuan untuk menilai kinerja keuangan suatu perusahaan yang disebut dengan ratarata industri. Jika rata-rata industri sebagai nilai tengah dalam derajat keanggotaan (gambar 3 dan gambar 4) maka didapatkan formula dengan mengadopsi fungsi 
keanggotaan linear untuk menghitung nilai matriks keputusan (formula 10 dan formula 11).

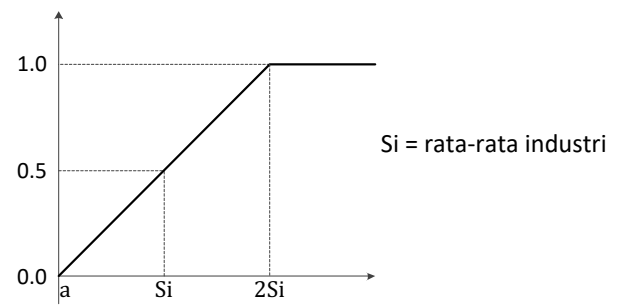

Gambar 3. Representasi matriks keputusan linear naik

Fungsi matriks keputusan linear naik:

$$
\mu[\mathrm{x}]= \begin{cases}1 ; & x \leq a \\ (x-a) /(2 S i-a) ; & a \leq x \leq b \\ 0 ; & x \geq b\end{cases}
$$

dimana $\mathrm{a}=0$ dan nilai $\mu[\mathrm{x}]$ tidak boleh lebih dari 1.0 .

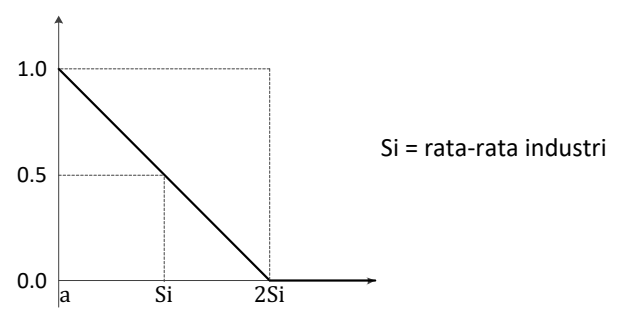

Gambar 4. Representasi matriks keputusan linear turun

Fungsi matriks keputusan linear naik:

$$
\mu[\mathrm{x}]= \begin{cases}1 ; & x \leq a \\ (2 S i-x) /(2 S i-a) ; & a \leq x \leq b \\ 0 ; & x \geq b\end{cases}
$$

dimana $\mathrm{a}=0$, nilai $\mu[\mathrm{x}]$ tidak boleh kurang dari 0.0 .

Dari perhitungan menggunakan representasi linear diatas didapatkan nilai matriks keputusan dalam bentuk bilangan fuzzy dengan tingkat presisi tiga digit desimal seperti terlihat dalam tabel 4 .

\begin{tabular}{|c|c|c|c|c|c|c|}
\hline \multirow{2}{*}{ Kriteria } & \multirow{2}{*}{ Jenis Rasio } & \multirow{2}{*}{$\begin{array}{l}\text { Fungsi } \\
\text { Linear }\end{array}$} & \multirow{2}{*}{$\begin{array}{l}\text { Rata- } \\
\text { rata } \\
\text { Industri }\end{array}$} & \multicolumn{3}{|c|}{ Bilangan Fuzzy } \\
\hline & & & & INDF & KLBF & UNVR \\
\hline $\mathrm{C} 1$ & Current Ratio & naik & 1.70 & 0.532 & 1.000 & 0.210 \\
\hline $\mathrm{C} 2$ & Quick Ratio & naik & 1.50 & 0.478 & 0.703 & 0.151 \\
\hline $\mathrm{C} 3$ & Cash Ratio & naik & 0.50 & 0.624 & 0.794 & 0.097 \\
\hline $\mathrm{C} 4$ & Debt to Asset Ratio & turun & 0.60 & 0.566 & 0.892 & 0.435 \\
\hline C5 & Debt to Equity Ratio & turun & 0.60 & 0.096 & 0.864 & 0.000 \\
\hline C6 & Long Term Debt to Equty Ratio & turun & 0.50 & 0.592 & 0.977 & 0.822 \\
\hline C7 & Equity Multiplier & turun & 1.00 & 0.000 & 0.367 & 0.000 \\
\hline $\mathrm{C} 8$ & Accounts Receivable Turnover & naik & 25 & 0.257 & 0.141 & 0.238 \\
\hline C9 & Inventory Turnover & naik & 17 & 0.162 & 0.085 & 0.220 \\
\hline $\mathrm{C} 10$ & Working Capital Turnover & naik & 7 & 0.111 & 0.153 & 0.389 \\
\hline C11 & Fixed Assets Turnover & naik & 3 & 0.482 & 0.850 & 0.783 \\
\hline $\mathrm{C} 12$ & Total Assets Turnover & naik & 2 & 0.185 & 0.349 & 0.604 \\
\hline $\mathrm{C} 13$ & Return on Assets & naik & 0.20 & 0.140 & 0.427 & 1.000 \\
\hline C14 & Return on Equity & naik & 0.30 & 0.195 & 0.360 & 1.000 \\
\hline $\mathrm{C} 15$ & Gross Profit Margin & naik & 0.28 & 0.479 & 0.255 & 0.885 \\
\hline C16 & Operating Profit Margin & naik & 0.23 & 0.246 & 0.346 & 0.489 \\
\hline $\mathrm{C} 17$ & Net Profit Margin & naik & 0.20 & 0.189 & 0.305 & 0.416 \\
\hline C18 & Price Earnings Ratio & turun & 8.00 & 0.120 & 0.680 & 0.000 \\
\hline C19 & Price to Book Value Ratio & turun & 6.00 & 0.890 & 0.419 & 0.000 \\
\hline
\end{tabular}

Tabel 4. Hasil matriks keputusan dalam bilangan fuzzy
Nilai-nilai dalam tabel tersebut yang akan dijadikan nilai input dalam metode TOPSIS sebagai matriks keputusan.

\section{Menentukan bobot preferensi kriteria}

Bobot preferensi dalam penelitian ini ditentukan berdasarkan profil resiko seorang investor, nilai bobot preferensi menunjukkan tingkat kepentingan relatif setiap kriteria atau subkriteria, tabel 5 menunjukkan bobot preferensi dengan profil resiko investasi menengah.

Tabel 5. Bobot preferensi setiap kriteria

\begin{tabular}{|l|r|r|r|r|r|r|r|}
\hline KRITERIA & $\mathrm{C} 1$ & $\mathrm{C} 2$ & $\mathrm{C} 3$ & $\mathrm{C} 4$ & $\mathrm{C} 5$ & $\mathrm{C} 6$ & $\mathrm{C} 7$ \\
\hline BOBOT & 1.00 & 1.00 & 1.00 & 1.00 & 1.00 & 0.75 & 1.00 \\
\hline TIPE & benefit & benefit & benefit & benefit & benefit & benefit & benefit \\
\hline
\end{tabular}

\begin{tabular}{|l|r|r|r|r|r|r|r|}
\hline KRITERIA & C8 & C9 & C10 & C11 & C12 & C13 & C14 \\
\hline BOBOT & 0.75 & 0.75 & 1.00 & 1.00 & 1.00 & 1.00 & 1.00 \\
\hline TIPE & benefit & benefit & benefit & benefit & benefit & benefit & benefit \\
\hline
\end{tabular}

\begin{tabular}{|l|r|r|r|r|r|}
\hline KRITERIA & $\mathrm{C} 15$ & $\mathrm{C} 16$ & $\mathrm{C} 17$ & $\mathrm{C} 18$ & $\mathrm{C} 19$ \\
\hline BOBOT & 1.00 & 1.00 & 1.00 & 0.50 & 0.50 \\
\hline TIPE & benefit & benefit & benefit & benefit & benefit \\
\hline
\end{tabular}

\section{Membuat matriks keputusan ternormalisasi}

Matrik keputusan ternormalisasi dapat dikalkulasi berdasarkan persamaan (3) seperti contoh berikut;

$$
\begin{aligned}
& r_{11}=\frac{0.532}{\sqrt{(0.532)^{2}+(1.000)^{2}+(0.210)^{2}}} \\
& r_{11}=0.462 ; \mathrm{dst} ;
\end{aligned}
$$

sehingga didapatkan hasil keseluruhan dari perhitungan

\begin{tabular}{|c|c|c|c|c|c|c|c|}
\hline ALTERNATIF & $\mathrm{C} 1$ & $\mathrm{C} 2$ & $\mathrm{C} 3$ & $\mathrm{C} 4$ & $\mathrm{C} 5$ & C6 & C7 \\
\hline INDF & 0.462 & 0.554 & 0.615 & 0.496 & 0.111 & 0.420 & 0.000 \\
\hline KLBF & 0.868 & 0.814 & 0.783 & 0.781 & 0.994 & 0.694 & 1.000 \\
\hline UNVR & 0.183 & 0.175 & 0.096 & 0.381 & 0.000 & 0.584 & 0.000 \\
\hline \begin{tabular}{|l|} 
ALTERNATIF \\
\end{tabular} & $\mathrm{C} 8$ & C9 & $\mathrm{C} 10$ & $\mathrm{C} 11$ & $\mathrm{C} 12$ & $\mathrm{C} 13$ & $\mathrm{C} 14$ \\
\hline INDF & 0.680 & 0.566 & 0.256 & 0.385 & 0.256 & 0.128 & 0.180 \\
\hline KLBF & 0.373 & 0.296 & 0.353 & 0.679 & 0.484 & 0.389 & 0.333 \\
\hline UNVR & 0.631 & 0.770 & 0.900 & 0.625 & 0.837 & 0.912 & 0.925 \\
\hline ALTERNATIF & $\mathrm{C} 15$ & $\mathrm{C} 16$ & $\mathrm{C} 17$ & $\mathrm{C} 18$ & $\mathrm{C} 19$ & & \\
\hline INDF & 0.461 & 0.381 & 0.344 & 0.174 & 0.905 & & \\
\hline KLBF & 0.245 & 0.534 & 0.556 & 0.985 & 0.426 & & \\
\hline UNVR & 0.853 & 0.755 & 0.757 & 0.000 & 0.000 & & \\
\hline
\end{tabular}
matrik keputusan seperti yang terlihat pada tabel 6 dengan tingkat presisi 3 digit desimal.

Tabel 6. Hasil perhitungan matriks ternormalisasi

\section{Membuat matriks keputusan normalisasi terbobot}

Bobot preferensi yang telah ditentukan sebelumnya akan digunakan untuk menentukan nilai-nilai matriks normalisasi terbobot, dengan perhitungan menggunakan persamaan (4) seperti contoh berikut;

$$
\begin{array}{ll}
\mathrm{Y}_{11}=1.000 * 0.462 & \mathrm{Y}_{11}=1.000 * 0.554 \\
\mathrm{Y}_{11}=0.462 ; & \mathrm{Y}_{11}=0.554 ; \mathrm{dst} ;
\end{array}
$$

maka diperoleh hasil keseluruhan seperti yang tertampil pada tabel 7 . 
Tabel 7. Hasil perhitungan matriks normalisasi terbobot \begin{tabular}{|l|l|l|l|l|l|l|l|}
\hline ALTERNATIF & C1 & C2 & C3 & C4 & C5 & C6 & C7 \\
\hline INDF & 0.462 & 0.554 & 0.615 & 0.496 & 0.111 & 0.315 & 0.000 \\
\hline KLBF & 0.868 & 0.814 & 0.783 & 0.781 & 0.994 & 0.521 & 1.000 \\
\hline UNVR & 0.183 & 0.175 & 0.096 & 0.381 & 0.000 & 0.438 & 0.000 \\
\hline
\end{tabular}

\begin{tabular}{|l|l|l|l|l|l|l|l|}
\hline ALTERNATIF & C8 & C9 & C10 & C11 & C12 & C13 & C14 \\
\hline INDF & 0.510 & 0.424 & 0.256 & 0.385 & 0.256 & 0.128 & 0.180 \\
\hline KLBF & 0.280 & 0.222 & 0.353 & 0.679 & 0.484 & 0.389 & 0.333 \\
\hline UNVR & 0.474 & 0.577 & 0.900 & 0.625 & 0.837 & 0.912 & 0.925 \\
\hline
\end{tabular}

\begin{tabular}{|l|c|c|c|c|c|}
\hline ALTERNATIF & C15 & C16 & C17 & C18 & C19 \\
\hline INDF & 0.461 & 0.381 & 0.344 & 0.087 & 0.452 \\
\hline KLBF & 0.245 & 0.534 & 0.556 & 0.492 & 0.213 \\
\hline UNVR & 0.853 & 0.755 & 0.757 & 0.000 & 0.000 \\
\hline
\end{tabular}

\section{Menentukan matriks solusi ideal positif dan negatif}

Untuk menentukan nilai-nilai dalam matriks solusi ideal perlu diperhatikan sifat masing-masing kriteria, apakah bersifat keuntungan (benefit) atau bersifat biaya (cost). Dengan memperhatikan tipe kriteria pada tabel 5 maka dapat ditentukan hasil matriks solusi ideal positif dan solusi ideal negatif seperti tertampil pada tabel 8 .

Tabel 8. Hasil solusi ideal positif dan solusi ideal negatif \begin{tabular}{|l|l|l|l|l|l|l|l|}
\hline ALTERNATIF & C1 & C2 & C3 & C4 & C5 & C6 & C7 \\
\hline $\mathrm{A}+$ & 0.868 & 0.814 & 0.783 & 0.781 & 0.994 & 0.521 & 1.000 \\
\hline $\mathrm{A}-$ & 0.183 & 0.175 & 0.096 & 0.381 & 0.000 & 0.315 & 0.000 \\
\hline
\end{tabular}

\begin{tabular}{|l|l|l|l|l|l|l|c|}
\hline ALTERNATIF & C8 & C9 & C10 & C11 & C12 & C13 & C14 \\
\hline $\mathrm{A}+$ & 0.510 & 0.577 & 0.900 & 0.679 & 0.837 & 0.912 & 0.925 \\
\hline $\mathrm{A}-$ & 0.280 & 0.222 & 0.256 & 0.385 & 0.256 & 0.128 & 0.180 \\
\hline
\end{tabular}

\begin{tabular}{|l|c|c|c|c|c|}
\hline ALTERNATIF & C15 & C16 & C17 & C18 & C19 \\
\hline A + & 0.853 & 0.755 & 0.757 & 0.492 & 0.452 \\
\hline A- & 0.245 & 0.381 & 0.344 & 0.000 & 0.000 \\
\hline
\end{tabular}

\section{Menentukan jarak antara nilai setiap alternatif}

Pengkalkulasian jarak Euclidean terbobot terhadap solusi ideal positif dengan persamaan (7) dan terhadap solusi ideal negatif dengan persamaan (8) maka didapatkan nilai untuk masing-masing alternatif seperti yang terlihat pada tabel 9.

Tabel 9. Hasil perhitungan jarak euclidean terbobot

\begin{tabular}{|l|r|r|}
\hline \multicolumn{1}{|c|}{ ALTERNATIF } & D + & \multicolumn{1}{c|}{ D- } \\
\hline INDF & 2.196 & 0.933 \\
\hline KLBF & 1.320 & 2.034 \\
\hline UNVR & 1.989 & 1.685 \\
\hline
\end{tabular}

\section{Menentukan nilai preferensi untuk setiap alternatif}

Untuk menentukan ranking masing-masing alternatif yang ada maka perlu dihitung terlebih dahulu nilai preferensi dari setiap alternatif. Dengan perhitungan berdasarkan persamaan (9) seperti contoh berikut;

$$
\begin{aligned}
& V_{1}=\frac{0.933}{0.933+2.196} \\
& V_{1}=0.298 ; \mathrm{dst} ;
\end{aligned}
$$

maka didapatkan hasil nilai preferensi dan ranking untuk masing-masing alternatif seperti terlihat pada tabel 10 .

Tabel 10. Hasil perhitungan nilai preferensi dan ranking

\begin{tabular}{|l|r|c|}
\hline \multicolumn{1}{|c|}{ ALTERNATIF } & \multicolumn{1}{c|}{ V } & Peringkat Rekomendasi \\
\hline INDF & 0.298 & 3 \\
\hline KLBF & 0.606 & 1 \\
\hline UNVR & 0.459 & 2 \\
\hline
\end{tabular}

\section{Hasil Metode F-TOPSIS}

Dengan perhitungan mengunakan metode F-TOPSIS didapatkan keputusan bahwa alternatif ke-2 yaitu saham Kalbe Farma Tbk (KLBF) yang memiliki laporan keuangan terbaik pada tahun 2014 dibandingkan alternatif lainnya, sehingga dapat menjadi rekomendasi terbaik untuk berinvestasi saham di tahun 2015 .

\subsection{Rancangan Data Flow Diagram}

Untuk pengembangan kedalam bentuk aplikasi web base, dibuatlah perancangan data flow diagram level 0 untuk penggambaran proses alur data didalam sistem seperti yang terlihat pada gambar 5 .

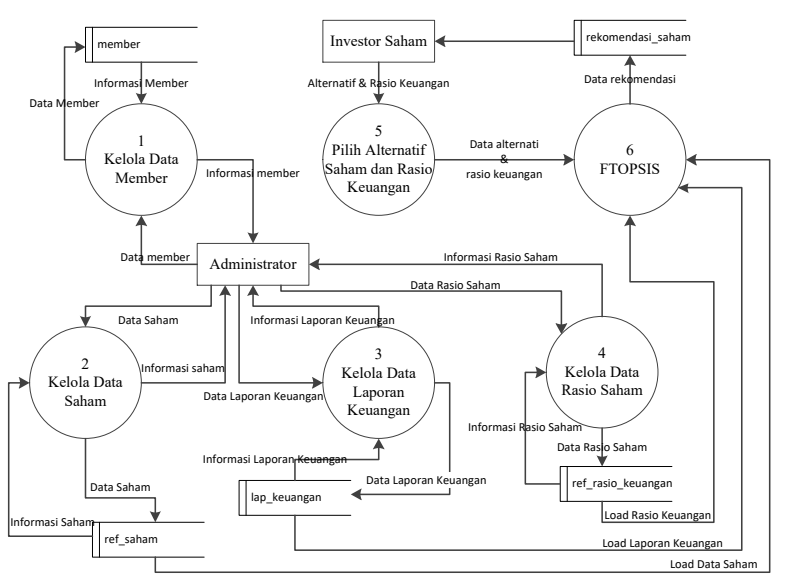

Gambar 5. Rancangan DFD Level 1

\subsection{Rancangan Database}

Dalam perancangan sistem terdapat entity yang saling terkait untuk menyediakan data-data yang dibutuhkan sistem, sehingga dibuatlah rancangan database seperti yang terlihat pada gambar 6 .

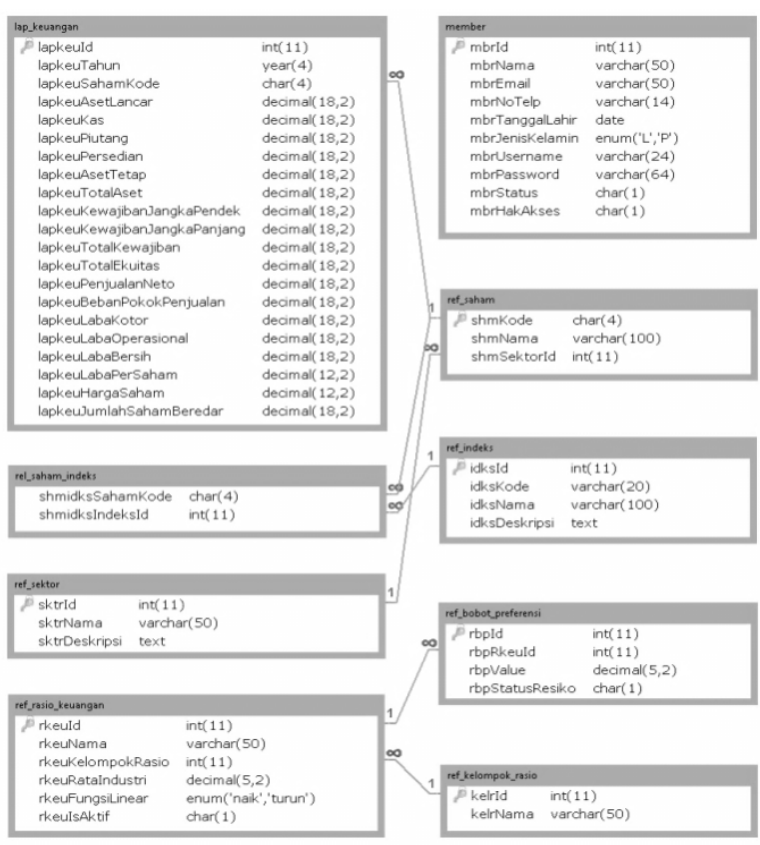

Gambar 6. Rancangan database 


\subsection{Alur Proses Sistem}

Garis besar alur proses sistem pendukung keputusan pemilihan saham terlihat seperti gambar 7 .

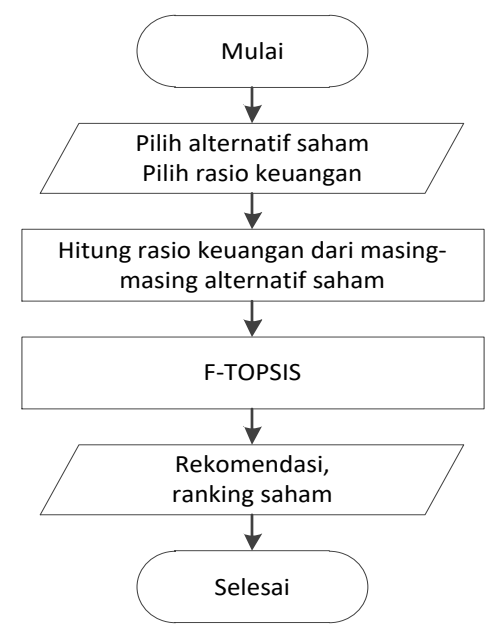

Gambar 7. Alur proses sistem pendukung keputusan

\subsection{Implementasi}

Dari proses implementasi yang telah dilakukan dapat dilihat hasil user interface yang telah dibuat seperti gambar 8 dan gambar 9 .

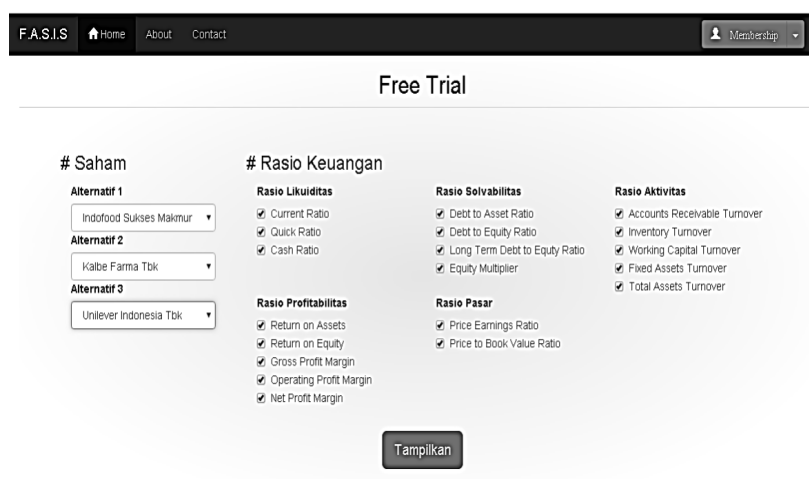

Gambar 8. Tampilan pilih alternatif dan kriteria

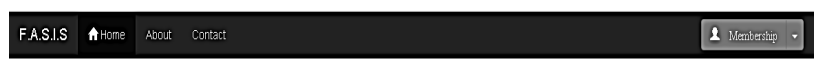
Free Trial

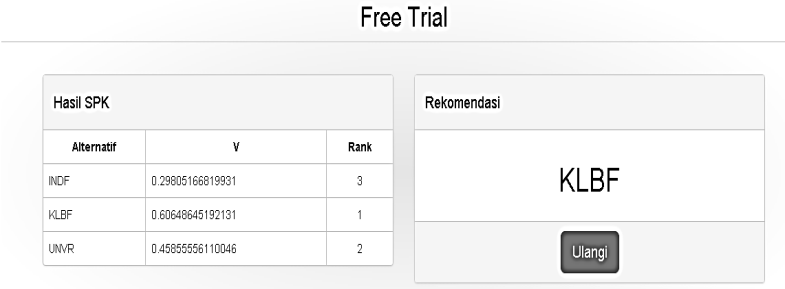

Gambar 9. Tampilan hasil SPK dan rekomendasi

\section{Kesimpulan}

Berdasarkan pembahasan dalam penelitian dapat diambil beberapa kesimpulan diantaranya:

1. Penggunaan bilangan fuzzy dengan penerapan representasi linear dalam pembuatan matriks keputusan mempermudah dalam menentukan bobot nilai masing-masing kriteria terhadap alternatif.
2. Penggunaan metode F-TOPSIS dapat menunjang analisis fundamental saham berdasarkan rasio keuangan lebih efektif dan efisien dalam memberikan rekomendasi alternatif berinvestasi saham, sehingga dapat membantu para investor menentukan pilihan berinvestasi saham jangka panjang.

\section{Daftar Pustaka}

[1] Liembono, RH., Analisis Fundamental, Jakarta: bei5000, 2014.

[2] Nofriansyah, Dicky., Konsep Data Mining VS Sistem Pendukung Keputusan, Yogyakarta: Deepublish, 2014.

[3] Lestari, Sri., "Implementasi Metode Fuzzy Technique for Order Preference by Similarity to Ideal Solution (TOPSIS) Untuk Seleksi Penerimaan Karyawan", in Tesis S2 Ilmu Komputer Universitas Gadjah Mada, Yogyakarta, 2011.

[4] Laymond S, Rajim., "Sistem Pendukung Keputusan Pemilihan Saham Berbasis Web Dengan Pemodelan AHP (Analytic Hierarchy Process) Dan Analisis Rasio Keuangan", in Tesis S2 Ilmu Komputer Universitas Gadjah Mada, Yogyakarta, 2013.

[5] Hartama, Dedy, "Seleksi Dosen Berprestasi Menggunakan FuzzyTOPSIS ," in Proc. KeTik 2014, pp. 219-224, November 2014.

[6] Setyawan, Yan Satria., "Implementasi Metode Fuzzy Analytical Hierarchy Process (F-AHP) Sebagai Pendukung Keputusan Investasi Pada Perusahaan Berdasarkan Rasio Keuangan (Studi Pada Perusahaan Farmasi Yang Terdaftar di BEI Periode 2013)", in Jurnal PTIIK Universitas Brawijaya, vol. 5, no. 10, 2015.

[7] Lumentut, Hence B., "Sistem Pendukung Keputusan untuk memilih Budidaya ikan air tawar menggunakan AF-TOPSIS", in Tesis S2 Ilmu Komputer Universitas Gadjah Mada, Yogyakarta, 2015.

[8] Heri., Analisis Laporan Keuangan Pendekatan Rasio Keuangan, Yogyakarta: CAPS, 2015.

[9] Wahyudiono, Bambang., Mudah Membaca Laporan Keuangan, Jakarta: Raih Asa Sukses, 2014.

\section{Biodata Penulis}

Angger Binuko Paksi, memperoleh gelar Sarjana Komputer (S.Kom), Jurusan Teknik Informatika STMIK AMIKOM Yogyakarta, lulus tahun 2014. Saat ini sedang menempuh studi pada Program Pasca Sarjana Magister Teknik Informatika di STMIK AMIKOM Yogyakarta dan bekerja sebagai Web Aplication Developer di PT. Gamatechno Indonesia. 